\title{
Pengaruh Atribut Produk dan Promosi Terhadap Minat Beli Konsumen Kota Pariaman di Toko Online Shopee
}

\author{
${ }^{1}$ Suhatman, ${ }^{2}$ Meri Rahmania Sari, ${ }^{3}$ Patria Nagara, ${ }^{4 *}$ Nasfi \\ 1,2,3Program Studi Manajemen, STIE Sumbar, Pariaman, Sumatera Barat \\ ${ }^{4}$ Prodi Perbankan Syariah, STES Manna Wa Salwa, Padang Panjang, Sumatera Barat \\ ${ }^{*}$ Corresponding Author: nasfi.anwar@gmail.com
}

\begin{abstract}
This study aims to determine the effect of product attributes and promotions on consumer buying interest in Kota Pariaman at Shopee online shop. The independent variables are product quality (X1), design (X2), features (X3), promotion (X4) and consumer interest (Y). The sample in this study were 97 online shop consumers in Kota Pariaman. The data collected are primary data using interviews / questionnaires and tools for analyzing SPSS data, 2019. The test uses regression analysis $\mathrm{Y} 0=4,967-0,016 \mathrm{X} 1+1,671 \mathrm{X} 2+0,291 \mathrm{X} 3+1,540 \mathrm{X} 4$. The results of the test show that partially the product attributes with product quality indicators have no effect, while design indicators, influential features, and promotions have an effect. And Ujif simultaneously product quality, design, features and promotions have a significant effect on consumer interest. With a determination of $68.3 \%$.
\end{abstract}

Keywords: Product Quality, Design, Features, Promotion and Consumer Interests

\section{Pendahuluan}

Kemajuan teknologi dan informasi yang semakin berkembang membuat perusahaanperusahan berusaha meningkatkan kualitas produknya menjadi lebih baik. Semua ini dilakukan agar perusahaan lebih kompetitif dari perusahaan lainnya, seperti sekarang, dimana tidak bisa dipungkiri lagi bahwa internet sudah menjadi kebutuhan yang sangat diperlukan oleh semua kalanganan. Teknologi informasi dan komunikasi (TIK) kini telah berkembang pesat dan hampir menguasai sebagian besar kehidupan manusia. Salah satu wujud dari TIK adalah dengan adanya internet (Wasis Ayu W, 2016).

Pemanfaatan internet kini telah dioptimalkan pada hampir seluruh aktifitas kehidupan, termasuk diantaranya dalam bidang ekonomi yang meliputi pemasaran barang dan jasa. Transaksi jual beli dengan menggunakan media internet lebih dikenal dengan istilah ecommerce. e-commerce adalah kegiatan bisnis yang menyangkut konsumen, manufaktur, pelayanan jasa, dan perdagangan perantara dengan menggunakan jaringan komputer, yaitu internet, engan kehadiran internet, sebagian para pebisnis mulai mengalihkan cara promosinya dan transaksi melalui E-e-commerce walaupun tidak meninggalkan cara promosi sebelumnya. Hal ini disebabkan oleh beberapa faktor keunggulan internet dibandingkan dengan media lainnya (Rusmawan, 2018).

Banyak orang yang mengalokasikan uang mereka dari iklan offline menjadi online. Banyak orang yang mengalokasikan dana mereka untuk berinvestasi di online sehingga bisa dilihat banyak sekali toko online atau e-commerce di Indonesia ini. Perkembangan e-commerce di Indonesia dapat dimanfaatkan menjadi peluang besar bagi sebagian orang yang dapat melihat potensi kedepannya. Pertumbuhan ini didukung dengan data dari Kemkominfo yang mengatakan bahwa nilai transaksi e-commerce pada tahun 2017 sudah mencapai angka 140 trilliun rupiah. Salah satu pelaku e-commerce yang saat ini berkembang adalah Shopee. Shopee tidak lepas dari perkembangan marketplace di Indonesia yang sangat pesat. Shopee

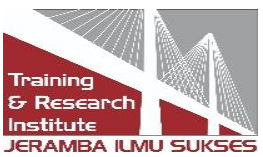


sendiri dikelola oleh Garena Group yang sekarang berubah nama menjadi SEA Group. Jika dibandingkan dengan situs marketplace lainnya seperti bukalapak, tokopedia, OLX dan lainlain, maka shopee termasuk yang termuda dan minim pengalaman. Namun dengan promosi yang gencar ee-commerce ini mampu berdiri sejajar dengan pesaing-pesaing terdahulunya tersebut (Prabowo \& Arofah, 2017).

Sejarah Shopee di Indonesia dimulai pada bulan Desember tahun 2015. Prestasi marketplace ini adalah keberhasilan promosi yang dalam waktu singkat, pengguna shopee tidak kalah banyak dari para pesaingnya. Shopee memudahkan para penjual serta pembeli dalam berinteraksi melalui fitur live chatnya. Sarana jual beli ini juga menyediakan banyak produk mulai dari gadget, fashion, kosmetik, elektronik, otomotif dan lain sebagainya (Prabowo \& Arofah, 2017).

Dilihat dari perkembangan e-commerce, maka perusahaan harus lebih fleksibel, ini akan menjadi suatu dorongan bagi perusahaan-perusahaan untuk selalu meningkatkan produk yang dihasilkannya baik dari segi kualitasnya maupun ragam produknya. Upaya yang harus dilakukan perusahaan dalam memenuhi keinginan dan kebutuhan konsumen serta mempertahankan kelangsungan hidup perusahaan adalah dengan melakukan strategi pemasaran yang tepat dan terarah, seperti meningkatkan atribut produk, kebijakan harga dan memilih saluran distribusi yang tepat untuk menghadapi persaingan yang ketat pada saat ini (Triandewi \& Tjiptono, 2013).

Dari 10 situs belanja online terpopuler di Indonesia, Shopee menduduki peringkat teratas dalam hal kunjungan konsumen, dengan kunjungan rata-rata 9:34 menit per konsumen. Sementara dari Survey yang dilakukan oleh e-IQ pada tahun 2018, diketahui bahwa reputasi Shopee juga dalam 6 besar peringkat dalam hal situs belanja online yang terpercaya (Karnadjaja et al., 2018).

Dari 6 situs belanja online memiliki reputasi baik di Indonesia, Shopee menduduki peringkat 6 dengan skor 10,9, sementara peringkat teratas diduduki oleh tokopedia dengan skor 14,3. Dilihat dari gender, kunjungan konsumen ke Shopee lebih dominan dari kaum perempuan. Kontribusi kunjungan dari kaum perempuan mengakses situs Shopee sebesar 58\% dan lakilaki sebanyak $42 \%$. Dilihat dari data di atas tentunya Shopee sebagai situs belanja online yang masih terbilang pendatang baru cukup diperhitungkan dalam persaingan situs belanja online. Ke depannya Shopee tentu harus lebih memacu kinerja untuk meraih pangsa pasar yang tumbuh dengan pesat (Febriani, 2020).

Usaha yang dilakukan perusahaan untuk memenuhi kebutuhan konsumen sekaligus memenangkan persaingan, perusahaan harus mempersiapkan strategi pemasaran yang tepat untuk produknya. Produk yang ditawarkan ke pasaran harus mendapatkan perhatian untuk dibeli, digunakan atau dikonsumsi agar memenuhi keinginan dan kebutuhan konsumen. Konsumen akan berusaha memenuhi kebutuhannya dan mencari manfaat tertentu dari suatu produk, dan konsumen akan mempertimbangkan produk mana yang akan dipilih untuk memenuhi kebutuhan dan memberikan manfaat yang diperlukan (Triandewi \& Tjiptono, 2013).

Perilaku konsumen dalam memilih produk di toko online, tentu saja akan dipengaruhi oleh atribut dari produk dari toko-toko tersebut. Atribut produk merupakan segala sesuatu yang melekat dan menyertai produk tersebut, seperti merek, desain, warna, kualitas dan sebagainya. Atribut merupakan salah satu unsur penting yang dapat mendorong konsumen untuk membeli 
produk, semakin baik atribut produk maka konsumen akan semakin tertarik untuk membeli produk tersebut (Firmansyah \& SE, 2019).

Berbagai macam atribut produk yang ditawarkan oleh perusahaan- perusahaan online, terutama Shopee. Konsumen dihadapkan dengan pilihan-pilihan yang banyak mengenai atribut produk produk yang dijual, karena atribut produk yang baik serta dapat memenuhi kebutuhan dan keinginan konsumen dapat menunjang perusahaan untuk tetap bertahan dalam persaingan seketat apapun. Dan saat ini Shopee memberikan fitur "tawar menawar" kepada konsumen. Sehingga konsumen dapat mendapatkan barang dengan harga yang cukup murah dari yang ditawarkan (Najmi, 2018).

Atribut produk yang ditawarkan oleh perusahaan-perusahaan pesaing Shopee tidak kalah hebatnya, seperti halnya Lazada sudah mempunyai merek yang bagus dibenak konsumen dan terkenal dengan pembayarannya yang sering didiscoun, Olx terkenal dengan produk-produk yang dijual secara face to face, Tokopedia yang mempunyai keunggulan dari segi aplikasinya yang menarik (Prabowo \& Arofah, 2017).

Menurut (Kotler \& Armstrong, 2015) mengelompokkan atribut produk kepada tiga unsur penting, yaitu kualitas produk (product quality), fitur produk (product features), dan desain produk (Product design). Kualitas produk yang sangat baik akan membangun kepercayaan konsumen sehingga merupakan penunjang kepuasan konsumen. Fitur produk identik dengan sifat dan sesuatu yang unik, khas dan istimewa yang tidak dimiliki oleh produk lainnya. Biasanya karakteristik yang melekat dalam suatu produk merupakan hasil pengembangan dan penyempurnaan secara terus menerus. Desain selain mempertimbangkan faktor penampilan, juga untuk bertujuan memperbaiki kinerja produk, mengurangi biaya produksi, dan menambah keunggulan bersaing.

Survei awal yang peneliti lakukan dengan melakukan wawancara pada 8 orang yang sering belanja online, ditemukan bahwa 5 orang tertarik berbelanja di situs Shopee dengan alasan mereka lebih mudah menemukan produk-produk yang mereka cari dan juga akses ke situs ini yang mudah dan juga pelayanan costumer service yang memuaskan, sementara 2 orang sering belanja di Lazada dengan alasan mereka sudah terbiasa belanja di toko online tersebut dan 1 orang belanja di Tokopedia karena sudah lama menjadi member toko tersebut dan juga karena seringnya muncul iklan-iklan promosi Shopee di televisi.

\section{Tinjauan Literatur}

\subsection{Kualitas Produk (Produkct Quality)}

Kualitas Proudk merupakan kecocokkan terhadap spesifikasi produk dan jasa yang dijanjikan sesuai keinginan dari kebutuhan konsumen baik secara fisik maupun psikologis (Nasfi et al., 2020). Dalam Kotler dan Amstrong kualitas produk adalah segala sesuatu yang ditawarkan dan mendapat perhatian pembeli, dimana kondisi tersebut berpengaruh kepada produk atau jasa serta harga dari produk tersebut.(Hismuddin et al., 2020).

\subsection{Desain (Desing)}

Menurut Perhimpuan Desainer Industri Amerika (IDSA) desain produk merupakan tahap dalam mengembangkan dan menciptakan nilai dan tampilan produk (Mustikasari, 2014). Desain produk merupakan tampilan, rasa maupun funsi dari produk yang mempengaruhi kebutuhan pelanggan untuk memperolehnya atau memilikinya (Nurmiati et al., 2020).

\subsection{Fitur (Features)}

Published by:

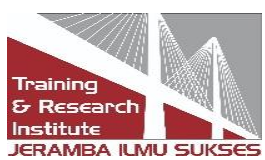


Fitur merupakan seperangkat komponen yang terdiri dari sifat-sifat produk berupa warna, kemasan maupun prestise dan pelayanan dari pabrik (Laheba et al., 2015). Sedangkan menurut Arif. M (2020) Fitur adalah komponen atau ciri khas dari produk yang diminati konsumen baik berupa bentuk, warna maupun prestisenya (Arif, M, Sabri, S, Nagara, P, Nasfi, 2020).

\subsection{Promosi (Promotion)}

Promosi merupakan rangkaian kegiatan pemasaran yang bertujuan untuk meningkatkan dan mendorong permintaan terhadap barang dan jasa (Meme \& Byre, 2020). Dan menurut Ramadonna (2019), promosi penjualan dalah bentuk persuasi langsung dengan jalan menggunakan berbagai hadiah maupun insentif yang bertujuan untuk merangsang calon konsumen melakukan pembelian (Ramadonna et al., 2019).

\subsection{Minat Konsumen (Custumer Interest)}

Menurut Hilgard yang dikutip oleh Slameto (2003:57) minat adalah "Kecenderungan yang tetap untuk memperhatikan dan mengenang beberapa kegiatan". Minat Konsumen merupakan ketertarikan atau kesukaan terhadap produk dan jasa untuk memilikinya (Hasim et al., 2020). Menurut Yenti (2020) minat konsumen merupakan darongan diri pribadi atau seseorang yang dipengaruhi merk, harga maupun pelayan produk, sehingga timbul keinginan memiliki dengan membeli produk dan jasa (Rosniyenti, Sabri, 2020).

\section{Metode Penelitian}

Lokasi Penelitian ini akan dilakukan di Kota Pariaman Sumatera Barat. Pertimbangan dalam mengambil lokasi ini adalah konsumen-konsumen yang berbelanja online pada perusahaan Shopee. Populasi penelitian erupakan gabungan dari seluruh elemen yang berbentuk peristiwa, hal atau orang yang memiliki karakteristik yang serupa yang menjadi pusat semesta penelitian (Arikunto, 2012). Dalam penelitian ini yang menjadi populasi adalah konsumen toko online di Kota Pariaman.

Dalam penelitian ini teknik pengambilan sampel yang digunakan adalah purposive sampling yaitu pengambilan sampel yang didasarkan pada karakteristik tertentu sesuai dengan kriteria yang telah ditetapkan dalam penelitian (Sugiyono, 2014). Besar sampel dalam penelitian ini adalah sebanyak 97 orang diambil dengan teknik accidental sampling, dengan rumus sebagai berikut:

$\mathrm{n}=\underline{\mathrm{z}^{2}}$.

$4(\mathrm{Moe})^{2}$

Dimana :

$\mathrm{Z} \quad=\quad$ tingkat keyakinan konsumen yang dibutuhkan dalam penentuan sampel

Moe $\quad=\quad$ Margin error atau kesalahan maksimum yang dapat ditoleransi

$\mathrm{n} \quad=$ Besarnya sampel

Tingkat keyakinan yang digunakan dalam penelitian ini adalah 95\% atau $\mathrm{z}=1,96$ (tabel distribusi normal) dan maka (Moe) $)^{2}=0,1$. Ukuran sampel dalam penelitian ini adalah sebagai berikut:

$$
\begin{aligned}
& \mathrm{n}=\frac{(1,96)^{2}}{4(0,1)^{2}} \\
& \mathrm{n}=96,04, \text { dibulatkan menjadi } 97
\end{aligned}
$$

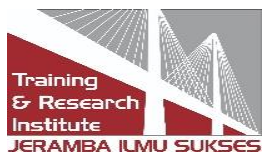


Jadi besar sampel dalam penelitian ini adalah sebanyak 97 orang diambil dengan teknik accidental sampling.

Ada 2 (dua) ) variabel utama yang menjadi fokus perhatian penelitian ini, yaitu variabel independen (bebas) dan dependen (terikat). Variabel produk fitur dan harga merupakan variabel bebas selanjutnya disebut variabel independen yang merupakan tipe variabel yang menjelaskan atau mempengaruhi variabel lain (Indrianto \& Supomo, 2011). Sedangkan variabel minat konsumen merupakan variabel terikat atau variabel dependen yang merupakan tipe variabel yang dijelaskan atau dipengaruhi variabel independen sesuai juga dengan penelitian (Ramadonna et al., 2019). Sedangkan variabel minat konsumen merupakan variabel terikat atau variabel dependen yang merupakan tipe variabel yang dijelaskan atau dipengaruhi variabel independen (Indrianto \& Supomo, 2011).
a. Kualitas produk
: variabel bebas / independen $\left(\mathrm{X}_{1}\right)$
b. Desain
: variabel bebas / independen $\left(\mathrm{X}_{2}\right)$.
c. Fitur
d. Promosi
: variabel bebas / independen $\left(\mathrm{X}_{3}\right)$.
e. Minat konsumen
: variabel bebas / independen $\left(\mathrm{X}_{4}\right)$
: variabel terikat / dependen (Y).

Metode pengumpulan data dalam penelitian ini adalah (1) Interview, yaitu suatu metode yang secara langsung mengadakan wawancara kepada koresponden dengan beberapa pertanyaan untuk mendapatkan data primer; (2) Quesioner, yaitu teknik pengambilan data dengan memberikan seperangkat pertanyaan atau pertanyaan tertulis kepada responden untuk menjawab.

\subsection{Uji Validasi dan Reliabilitasi Instrumen Penelitian}

1. Uji validitas

Uji Validitas Item adalah uji statistik yang digunakan guna menentukan seberapa valid suatu item pertanyaan mengukur variabel yang diteliti. Uji validitas digunakan dengan membandingkan antara nilai total item corelation dengan nilai 0,3. Apabila nilai total item corelation > 0,3 maka item pertanyaan dinyatakan valid

2. Uji Reliabilitas

Uji Reliabilitas dilakukan dengan uji Alpha Cronbach. Rumus Alpha Cronbach sebagai berikut:

Teknik Analisa Data dengan Statistik Deskriptif yang merupakan metode-metode yang berkaitan dengan pengumpulan dan penyajian suatu gugus data sehingga memberikan informasi yang berguna. Pengklasifikasian menjadi statistika deskriptif dan statistika inferensia dilakukan berdasarkan aktivitas yang dilakukan.

Sedangkan untuk mencari tingkat pencapaian jawaban responden digunakan rumus berikut :

$\mathrm{TCR}=\frac{\text { Rata }- \text { Rata } \text { Skor }}{5}$

Dimana : TCR $=$ Tingkat pencapaian jawaban responden

Arikunto (2002) mengemukakan kriteria jawaban responden sebagai berikut :

Jika TCR berkisar antara $90-100 \%=$ Sangat baik

Jika TCR berkisar antara $80-89 \%=$ Baik

Jika TCR berkisar antara $65-79 \%=$ Cukup baik

Jika TCR berkisar antara $56-64 \%=$ Kurang baik

Jika TCR berkisar antara $0-54 \%=$ Tidak baik 


\subsection{Uji asumsi Klasik}

\section{a. Uji Normalitas}

Uji normalitas dilakukan untuk mengetahui apakah model regresi, variabel independent, variabel dependent, atau keduanya mempunyai distribusi normal atau tidak. Untuk mengetahuinya digunakan uji Kolmongorov-Smirnov, menurut (Indrianto \& Supomo, 2011) pedoman pengambilan keputusan dalam uji normalitas yaitu, bila nilai Sig atau signifikan lebih besar daripada 0,05 maka distribusi adalah normalitas (simetris) (Nasfi, Rahmad, 2020).

\section{b. Uji Heteroskedastisitas}

Uji heteroskedastisitas digunakan untuk mengetahui ada atau tidaknya penyimpangan asumsi klasik heteroskedastisitas yaitu adanya ketidaksamaan varian dari residual untuk semua pengamatan pada model regresi. Heteroskedastisitas merupakan salah satu faktor yang menyebabkan model regresi linier sederhana tidak efisien dan akurat, juga mengakibatkan penggunaan metode kemungkinan maksimum dalam mengestimasi parameter (koefisien) regresi akan terganggu. Untuk mengetahui ada tidaknya heteroskedastisitas dalam penelitian ini mengunakan metode Sperman Rank Corellation. Apabila hasil pengujian menunjunkan lebih dari $\alpha=5 \%$ maka tidak ada heteroskedastisitas (Rahmad et al., 2020).

\section{c. Uji Multikolinieritas}

Uji multikolinieritas adalah uji yang dilakukan untuk memastikan apakah di dalam sebuah model regresi ada interkorelasi atau kolinearitas antar variabel bebas. Interkorelasi adalah hubungan yang linear atau hubungan yang kuat antara satu variabel bebas atau variabel prediktor dengan variabel prediktor lainnya di dalam sebuah model regresi. Interkorelasi itu dapat dilihat dengan nilai koefisien korelasi antara variabel bebas, nilai VIF dan Tolerance. Jika nilai VIF $<10$ dan nilai tolerance lebih dari 0,10 , maka dapat dinyatakan tidak terjadi multikolinieritas.

\subsection{Uji Regresi Berganda}

Analisis ini untuk mengetahui arah hubungan antara variabel independen dengan variabel dependen apakah masing-masing variabel independen berhubungan positif atau negatif dan untuk memprediksi nilai dari variabel dependen apabila nilai variabel independen mengalami kenaikan atau penurunan. Data yang digunakan biasanya berskala interval atau rasio.

Persamaan : $Y=\beta 0+\beta_{1} X_{1}+\beta_{2} X_{2}+\beta_{3} X_{3}+\beta_{4} X_{4}+e$

Keterangan :

$\begin{array}{ll}\mathrm{Y} & : \text { Minat Konsumen } \\ \beta 0 & : \text { Konstanta } \\ \beta_{1}, \beta_{2} & : \text { Koefisien Regresi } \\ \mathrm{X}_{1} & : \text { Variabel Kualitas produk } \\ \mathrm{X}_{2} & : \text { Variabel Desain } \\ \mathrm{X}_{3} & : \text { Variabel Fitur } \\ \mathrm{X}_{4} & : \text { Variabel Promosi } \\ \mathrm{e} & : \text { Standar eror }\end{array}$




\subsection{Pengujian Hipotesis}

a. Pengujian secara parsial (Uji t)

Uji t dikenal dengan uji parsial, yaitu untuk menguji bagaimana pengaruh masing-masing variabel bebasnya secara sendiri-sendiri terhadap variabel terikatnya. Uji ini dapat dilakukan dengan mambandingkan $t$ hitung dengan $t$ tabel atau dengan melihat kolom signifikansi pada masing-masing $\mathrm{t}$ hitung atau nilai probabilitas signifikansi lebih besar dari 0,05 (tingkat kepercayaan yang dipilih) maka hipotesis nol (Ho) diterima dan hipotesis alternatif (Ha) ditolak atau sebaliknya.

Pengujian setiap koefisien regresi dikatakan signifikan bila nilai mutlak $t_{\text {hit }}>t_{\text {tabel }}$ atau nilai probabilitas signifikansi lebih kecil dari 0,05 (tingkat kepercayaan yang dipilih) maka hipotesis nol (Ho) ditolak dan hipotesis alternatif (Ha) diterima, sebaliknya dikatakan tidak signifikan bila nilai $t_{\text {hit }}<t_{\text {tabel }}$ atau nilai probabilitas signifikansi lebih besar dari 0,05 (tingkat kepercayaan yang dipilih) maka hipotesis nol (Ho) diterima dan hipotesis alternatif (Ha) ditolak (Santoso, 2012).

\section{b. Uji F}

Uji F dikenal dengan Uji serentak atau uji Model/Uji Anova, yaitu uji untuk melihat bagaimanakah pengaruh semua variabel bebasnya secara bersama-sama terhadap variabel terikatnya. Atau untuk menguji apakah model regresi yang kita buat baik/signifikan atau tidak baik/non signifikan.

Uji $\mathrm{F}$ dapat dilakukan dengan membandingkan $\mathrm{F}$ hitung dengan $\mathrm{F}$ tabel, jika $\mathrm{F}$ hitung $>$ dari $\mathrm{F}$ tabel, (Ho di tolak Ha diterima) maka model signifikan atau bisa dilihat dalam kolom signifikansi pada Anova. Dan sebaliknya jika $\mathrm{F}$ hitung < $\mathrm{F}$ tabel, maka model tidak signifikan, hal ini juga ditandai nilai kolom signifikansi (5\%) akan lebih besar dari alpha (Santoso, 2012).

\section{c. Analisis Koefisien Determinasi $\left(\mathrm{R}^{2}\right)$}

Koefisien determinasi $\left(\mathrm{R}^{2}\right)$ dipergunakan untuk mengetahui sampai seberapa besar prosentase variasi variabel bebas pada model dapat diterangkan oleh variabel terikat. Koefisien determinasi $\left(\mathrm{R}^{2}\right)$ dinyakan dalam persentase. Nilai Adjust $\mathrm{R}^{2}$ ini berkisar antara $0<\mathrm{R}^{2}<1$ (Santoso, 2012).

\section{Hasil dan Pembahasan}

\subsection{Pengaruh Kualitas produk dengan Minat konsumen}

Hasil penelitian terhadap pengaruh variabel kualitas produk terhadap minat konsumen ditemukan hasil bahwa thitung $=-0,179$ dengan nilai signifikansi 0,859, keputusan Ha ditolak sehingga dapat dinyatakan bahwa tidak ada pengaruh kualitas produk terhadap minat beli

Hasil ini sesuai dengan teori bahwa kualitas produk merupakan salah satu faktor yang akan membangun kepercayaan konsumen sehingga merupakan penunjang kepuasan konsumen. Akan apabila konsumen lebih tertarik terhadap produk karena faktor lain, maka kualitas produk bisa menjadi faktor yang tidak terlalu menjadi pertimbangan dalam minat mereka terhadap suatu produk.

Menurut (Ramadonna et al., 2019) minat konsumen merupakan segala sesuatu yang diinginkan individu yang menyangkut proses konsumsi barang dan jasa baik sebelum atau 
sesudahnya. Perilaku konsumen meliputi bagaimana seorang konsumen memutuskan untuk memilih sebuah produk, baik dari segi harga, daya tarik, keberagaman ataupun kualitas.

Berdasarkan teori di atas, maka keinginan konsumen dalam hal membeli produk Shopee lebih karena faktor lain, karena jika dilihat dari faktor kualitas, konsumen yang tidak berhadapan langsung dengan produk yang dibeli tentu tidak memahami atau tidak mengenal bagaimana kualitas barang tersebut, ketika diraba, dilihat langsung ataupun dicoba terlebih dahulu (Nasfi et al., 2020).

Hasil penelitian ini berbeda dengan penelitian yang dilakukan oleh (Basjaruddin et al., 2017) dimana kualitas produk mempengaruhi minat beli konsumen terhadap belanja toko online Tokopedia. Sementara penelitian (Sopiyan, Pipih Gunawan, 2018), juga ditemukan bahwa ada pengaruh atribut produk terhadap minat beli. Demikian juga penelitian oleh (Kusumawardhana, 2016) bahwa ada pengaruh atribut produk terhadap minat beli konsumen Yamaha.

\subsection{Pengaruh Desain dengan Minat konsumen}

Hasil penelitian terhadap pengaruh variabel desain terhadap minat konsumen ditemukan hasil bahwa thitung $=8,176$ dengan nilai signifikansi 0,000 , keputusan Ha diterima sehingga dapat dinyatakan bahwa ada pengaruh desain terhadap minat beli.

Sesuai dengan teori bahwa desain dengan minat memiliki hubungan saling mempengaruhi, dimana (Kotler \& Armstrong, 2015) mengartikan desain atau rancangan adalah totalitas keistimewaan yang mempengaruhi penampilan fungsi produk dari segi kebutuhan pelanggan. Sesuai dengan penelitian yang dilakukan oleh (Gunawan, 2009), dimana variabel desain produk pada atribut produk mempengaruhi minat beli konsumen terhadap Honda CRV.

Penelitian yang dilakukan memiliki kesamaan hasil dengan penelitian oleh (Gunawan, 2009) dimana pada penelitiannya tentang pengaruh atribut produk terhadap minat beli konsumen pada Honda CR-V di IBRM Bandung, ditemukan bahwa faktor desain mempengaruhi minat beli konsumen. Demikian juga penelitian oleh (Kusumawardhana, 2016) bahwa ada pengaruh atribut produk terhadap minat beli konsumen Yamaha.

\subsection{Pengaruh Fitur dengan Minat konsumen}

Hasil penelitian terhadap pengaruh variabel fitur terhadap minat konsumen ditemukan hasil bahwa thitung $=2,459$ dengan nilai signifikansi 0,016, keputusan Ha diterima sehingga dapat dinyatakan bahwa ada pengaruh fitur terhadap minat beli.

Sesuai dengan teori bahwa fitur produk identik dengan sifat dan sesuatu yang unik, khas dan istimewa yang tidak dimiliki oleh produk lainnya. Biasanya karakteristik yang melekat dalam suatu produk merupakan hasil pengembangan dan penyempurnaan secara terus menerus.

Sesuai dengan penelitian yang dilakukan oleh (Kusumawardhana, 2016), dimana fitur pada atribut produk mempengaruhi minat beli konsumen terhadap Motor Yamaha. Demikian juga penelitian(Gunawan, 2009) juga ditemukan bahwa ada pengaruh atribut produk terhadap minat beli.

\subsection{Pengaruh Promosi dengan Minat konsumen}

Hasil penelitian terhadap pengaruh variabel promosi terhadap minat konsumen ditemukan hasil bahwa thitung $=6,555$ dengan nilai signifikansi 0,000, keputusan Ha diterima sehingga dapat dinyatakan bahwa ada pengaruh promosi terhadap minat beli.

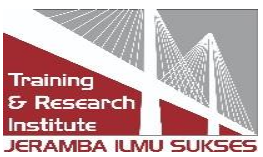


Tujuan merupakan petunjuk dalam melakukan alat-alat promosi penjualan yang tepat dan juga sebagai dasar evaluasi pelaksanaan program tersebut. Tujuan- tujuan tersebut harus berdasarkan konsep dasarnya,yaitu program promosi penjualan ini merupakan salah satu strategi pemasaran yang dilaksanakan perusahaan (Alma, 2013). Karena pengaruh utama yang diharapkan dari program promosi penjualan ini adalah untuk mendorong konsumen atau distributor melakukan tindakan pembelian.

Sesuai dengan penelitian yang dilakukan oleh (Kara, 2016), dimana promosi mempengaruhi minat beli konsumen terhadap penjualan pakaian online shop elevenia di BBM Group.

\subsection{Pengaruh Kualitas Produk, Desain, Fitur dan Promosi secara bersama terhadap Minat konsumen}

Berdasarkan hasil penelitian ditemukan bahwa nilai signifikan yang dihasilkan didalam pengujian adalah sebesar 0,000 di dalam tahapan pengujian data digunakan tingkat kesalahan atau alpha sebesar 0,05. Hasil perhitungan statistik menunjukkan nilai $\mathrm{F}$ hitung $=49,660$ dengan signifikansi sebesar $0,000<0,05$. Dengan nilai signifikansi di bawah 0,05. Maka keputusannya adalah Ho ditolak dan Ha diterima sehingga dapat disimpulkan bahwa kualitas produk, desain, fitur dan promosi secara bersama sama berpengaruh signifikan terhadap minat beli konsumen Shopee

Perilaku konsumen dalam memilih produk di toko online, tentu saja akan dipengaruhi oleh atribut dari produk dari toko-toko tersebut. Atribut produk merupakan segala sesuatu yang melekat dan menyertai produk tersebut, seperti merek, desain, warna, kualitas dan sebagainya. Atribut merupakan salah satu unsur penting yang dapat mendorong konsumen untuk membeli produk, semakin baik atribut produk maka konsumen akan semakin tertarik untuk membeli produk tersebut.

Sejalan dengan penelitian yang dilakukan oleh (Kusumawardhana, 2016) tentang pengaruh atribut produk terhadap minat beli konsumen Yamaha Vixion (Studi Kasus Pada Mahasiswa Widyatama Bandung) ditemukan bahwa secara bersamaan atribut produk mempengaruhi terhadap minat beli konsumen.

\subsection{Uji Asumsi Klasik}

Uji asumsi klasik adalah persyaratan statistik yang harus dipenuhi pada analisis regresi linear berganda. Ada tiga uji asumsi klasik yang dilakukan pada penelitian ini, yaitu uji multikolinearitas, uji heteroskedastisitas, uji normalitas. Berikut penjabaran masing-masing uji yang dilakukan

\section{1) Uji Normalitas}

Sebelum dilakukan pengujian hipotesis terlebih dahulu dilakukan pengujian normalitas. Menurut (Ghozali \& Latan, 2015) pengujian normalitas dilakukan untuk mengetahui pola distribusi variabel yang mendukung masing masing variabel uji One Sample Kolmogorov Smirnov Test. Di dalam pengujian normalnya masing masing variabel penelitian ditentukan dari nilai asymp sig (2-tailed) diatas 0,05. Berdasarkan hasil pengujian yang telah dilakukan diperoleh ringkasan hasil terlihat pada Tabel 1 di bawah ini ; 
Tabel 1. Hasil Uji Normalitas Variabel Penelitian

One-Sample Kolmogorov-Smirnov Test

\begin{tabular}{|c|c|c|c|c|c|c|}
\hline & kualitas & desain & fitur & promosi & minat konsumen \\
\hline \multicolumn{2}{|l|}{$\mathrm{N}$} & 97 & 97 & 97 & 97 & 97 \\
\hline \multirow{2}{*}{$\begin{array}{l}\text { Normal } \\
\text { Parameters }\end{array}$} & Mean & 62.43 & 52.87 & 47.00 & 37.64 & 38.10 \\
\hline & $\begin{array}{l}\text { Std. } \\
\text { Deviation }\end{array}$ & 5.488 & 3.610 & 3.979 & 3.049 & 2.981 \\
\hline \multirow{3}{*}{$\begin{array}{l}\text { Most } \\
\text { Differences }\end{array}$} & Absolute & .109 & .133 & .133 & .155 & .108 \\
\hline & Positive & .109 & .088 & .133 & .091 & .108 \\
\hline & Negative & -.108 & -.133 & -.133 & -.155 & -.103 \\
\hline \multicolumn{2}{|c|}{ Kolmogorov-Smirnov Z } & 1.076 & 1.313 & 1.307 & 1.530 & 1.066 \\
\hline \multicolumn{2}{|c|}{ Asymp. Sig. (2-tailed) } & .017 & .043 & .036 & .019 & .006 \\
\hline
\end{tabular}

a. Test distribution is Normal.

Sumber: Hasil Pengolahan Data SPSS, 2019)

Dari Tabel 1 terlihat bahwa masing masing variabel yang terdiri dari kualitas produk, desain, fitur, promosi dan Minat konsumen telah memiliki nilai asymp sig > alpha 0.05. Jadi dapat disimpulkan bahwa seluruh variabel penelitian yang digunakan didalam penelitian ini telah berdistribusi normal. Jadi proses pengolahan data dapat dilanjutkan ke tahapan berikutnyat.

2) Uji Heterokedastisitas

Penelitian yang menggunakan analisis regresi, mengharapkan hasil pengamatan yang homokedastisitas, yang berarti terjadinya faktor gangguan masih dalam batas normal. Penyimpangan dari asumsi ini adalah heterokedastisitas. Oleh karena itu dalam analisis regresi harus dilakukan pengujian untuk mengetahui ada tidaknya gejala heterokedastisitas adalah metode scatterplot

Gambar 1. Hasil Uji Heterokedastisitas

Scatterplot

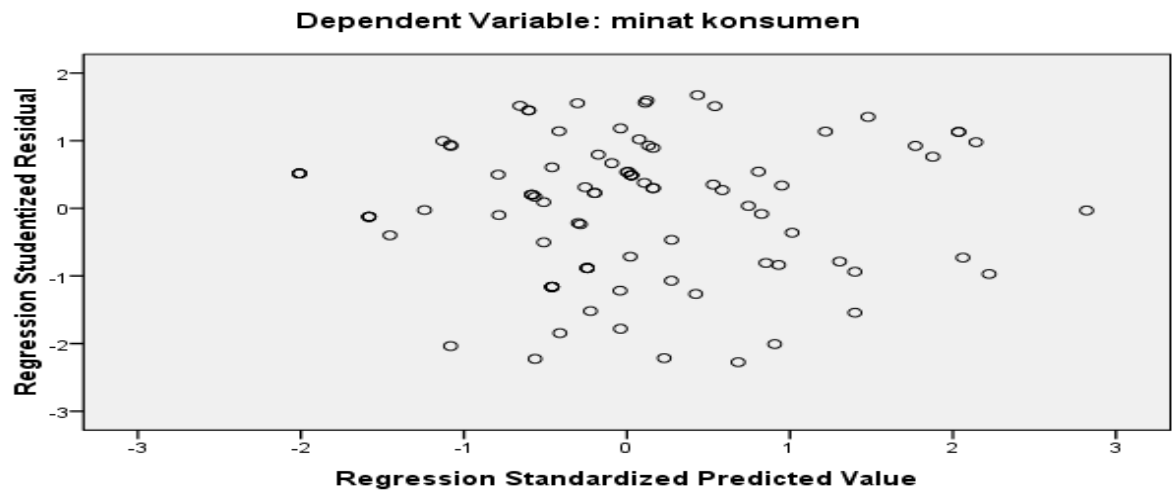

Dari gambar Scatterplot dapat dilihat bahwa tidak ada pola yang jelas serta titik menyebar diatas dan dibawah angka nol pada sumbu y, maka dapat dinyatakan tidak terjadi heterokedastisitas. 
3) Uji Multikolinearitas

Pengujian terhadap gejala multikolinearitas dilakukan untuk mengetahui apakah ada hubungan linier yang "sempurna" atau mendekati sempurna. Model regresi yang baik seharusnya tidak terjadi korelasi sempurna atau mendekati sempurna diantara variabel bebasnya. Apabila ada beberapa atau semua variabel independen berkorelasi kuat, dapat dikatakan terdapat multikolinearitas dalam model persamaan regresi yang digunakan. Hal ini mengakibatkan ketidakpastian dalam membuat estimasi, sehingga mengarah pada kesimpulan yang menerima hipotesis nol.

Untuk mendeteksi apakah antara variabel independen yang digunakan mempunyai koloniearitas yang tinggi atau tidak, digunakan Pearson Correlation Matrix, Tolerance (TOL), dan Variance Inflation Factor (VIF).

Tabel 2. Hasil Uji Multikolinearitas

\section{Coefficients $^{\mathrm{a}}$}

\begin{tabular}{|c|c|c|c|}
\hline \multirow{2}{*}{\multicolumn{2}{|c|}{ Model }} & \multicolumn{2}{|c|}{ Collinearity Statistics } \\
\hline & & Tolerance & VIF \\
\hline \multirow[t]{4}{*}{1} & kualitas & .127 & 7.902 \\
\hline & desain & .056 & 17.816 \\
\hline & fitur & .138 & 7.242 \\
\hline & promosi & .060 & 16.775 \\
\hline
\end{tabular}

a. Dependent Variable: minat konsumen

Sumber : Hasil pengolahan data primer, 2019

Dari output dapat dilihat bahwa nilai tolerance untuk semua variabel independen lebih dari 0,10. (Ghozali \& Latan, 2015), jika nilai TOL lebih besar dari 0,10 maka tidak terdapat Multikolinearitas dalam model regresi yang digunakan. Selanjutnya, nilai Variance Inflation Factor (VIF) untuk semua variabel independen dalam penelitian ini kurang dari 5

\subsection{Analisa Regresi Berganda}

Analisis regresi berganda berguna untuk menganalisis hubungan linear antara 2 variabel indepeden atau lebih dengan satu variabel dependen. Untuk melengkapi taapan pengujian hipotesis terlebih dahulu sebelum pengujian tersebut dilakukan maka perlu dilakukan rangkaian pengujian statistic seperti yang dapat dilihat pada tabel dibawah ini 
Tabel 3. Uji Regresi

\section{Coefficients $^{\mathrm{a}}$}

\begin{tabular}{|l|r|r|r|r|r|}
\hline \multirow{2}{*}{ Model } & \multicolumn{2}{|c|}{$\begin{array}{c}\text { Unstandardized } \\
\text { Coefficients }\end{array}$} & \multicolumn{2}{c|}{$\begin{array}{c}\text { Standardized } \\
\text { Coefficients }\end{array}$} & \multirow{2}{*}{} \\
\cline { 2 - 4 } & \multicolumn{1}{|c|}{$\mathrm{B}$} & Std. Error & \multicolumn{1}{c|}{ Beta } & \multicolumn{1}{c|}{$\mathrm{t}$} & \multicolumn{1}{c|}{ Sig. } \\
\hline 1 (Constant) & 4.967 & 3.165 & & -1.569 & .120 \\
kualitas & -.016 & .090 & -.029 & -.179 & .859 \\
desain & 1.671 & .204 & 2.024 & 8.176 & .000 \\
fitur & .291 & .118 & .388 & 2.459 & .016 \\
promosi & 1.540 & .235 & -1.575 & 6.555 & .000 \\
\hline
\end{tabular}

a. Dependent Variable: minat konsumen

Sumber : Hasil pengolahan data primer, 2019

Dalam tabel tersebut terlihat bahwa nilai:

$\mathrm{Y}_{0}=4,967-0,016 \mathrm{X}_{1}+1,671 \mathrm{X}_{2}+0,291 \mathrm{X}_{3}+1,540 \mathrm{X}_{4}$

Jika $a_{0}$, $a_{1}$, dan $a_{2}$, dimasukkan ke dalam model persaman regresi, maka didapat model persamaan regresi sebagai berikut:

Minat konsumen $=4,967+-0,016$ kualitas produk $+1,671$ desain $+0,291$ fitur $+1,540$ promosi $+\mathrm{e}_{\mathrm{i}}$

Persamaan tersebut dapat ditafsirkan bahwa rata-rata minat konsumen adalah sebesar 4,967 jika tidak terdapat perubahan variabel kualitas produk, desain, fitur dan promosi. Nilai koefisien regresi setiap variabel bebas dalam model persamaan regresi linier menunjukkan besar dan arah hubungan masing-masing variabel bebas terhadap variabel terikat. Perubahan 1 unit kualitas produk menyebabkan minat konsumen berubah sebanyak -0,016. Perubahan 1 unit desain menyebabkan minat konsumen berubah sebanyak 1,671. Perubahan 1 unit fitur menyebabkan minat konsumen berubah sebanyak 0,291 dan Perubahan 1 unit promosi menyebabkan minat konsumen berubah sebanyak 1,540.

\subsection{Uji Hipotesis}

a) $\mathrm{Uji} T$ 
Tabel 4. Faktor-faktor yang Mempengaruhi terhadap Minat konsumen

\section{Coefficients $^{\text {a }}$}

\begin{tabular}{|l|r|r|r|r|r|}
\hline \multirow{2}{*}{ Model } & \multicolumn{2}{|c|}{$\begin{array}{c}\text { Unstandardized } \\
\text { Coefficients }\end{array}$} & $\begin{array}{c}\text { Standardized } \\
\text { Coefficients }\end{array}$ & \multirow{2}{*}{ Sig. } \\
\cline { 2 - 4 } & \multicolumn{1}{|c|}{$\mathrm{B}$} & Std. Error & \multicolumn{1}{c|}{ Beta } & \multicolumn{1}{c|}{$\mathrm{t}$} & \multicolumn{1}{c|}{ Sig } \\
\hline 1 (Constant) & 4.967 & 3.165 & & -1.569 & .120 \\
kualitas & -.016 & .090 & -.029 & -.179 & .859 \\
desain & 1.671 & .204 & 2.024 & 8.176 & .000 \\
fitur & .291 & .118 & .388 & 2.459 & .016 \\
promosi & 1.540 & .235 & -1.575 & 6.555 & .000 \\
\hline
\end{tabular}

a. Dependent Variable: minat konsumen

Sumber : Hasil pengolahan data primer, 2019

Berdasarkan tabel 4 maka diperoleh hasil

1. Variabel kualitas produk thitung $=-0,179$ dengan nilai signifikansi 0,859 , keputusan $\mathrm{Ha}$ ditolak sehingga dapat dinyatakan bahwa tidak ada pengaruh kualitas produk terhadap minat beli

2. Variabel desain thitung $=8,176$ dengan nilai signifikansi 0,000 , keputusan Ha diterima sehingga dapat dinyatakan bahwa ada pengaruh desain terhadap minat beli

3. Variabel fitur thitung $=2,459$ dengan nilai signifikansi 0,016 , keputusan Ha diterima sehingga dapat dinyatakan bahwa ada pengaruh fitur terhadap minat beli

4. Variabel promosi thitung $=6,555$ dengan nilai signifikansi 0,000 , keputusan Ha diterima sehingga dapat dinyatakan bahwa ada pengaruh promosi terhadap minat beli

b) Uji F

Menurut (Ghozali \& Latan, 2015) uji F adalah uji yang digunakan untuk mengetahui pengaruh variabel dependen secara bersama sama. Uji $\mathrm{F}$ juga dilakukan untuk menguji kelayakan model. Berdasarkan hasil pengolahan data yang telah dilakukan diperoleh ringkasan hasil seperti terlihat pada Tabel 4.21 di bawah ini:

Tabel 5. Hasil Uji F

ANOVA

\begin{tabular}{|l|r|r|r|r|r|}
\hline Model & Sum of Squares & df & Mean Square & F & Sig. \\
\hline 1 Regression & 582.968 & 4 & 145.742 & 49.660 & $.000^{\mathrm{a}}$ \\
Residual & 270.001 & 92 & 2.935 & & \\
Total & 852.969 & 96 & & & \\
\hline
\end{tabular}

a. Predictors: (Constant), promosi, fitur, kualitas, desain

b. Dependent Variable: minat konsumen

Sumber : Hasil pengolahan data primer, 2019

Berdasarkan Tabel 5 terlihat bahwa nilai signifikan yang dihasilkan didalam pengujian adalah sebesar 0,000 di dalam tahapan pengujian data digunakan tingkat kesalahan atau alpha sebesar 
0,05 . Hasil perhitungan statistik menunjukkan nilai $\mathrm{F}$ hitung $=49,660$ dengan signifikansi sebesar $0,000<0,05$. Dengan nilai signifikansi di bawah 0,05. Maka keputusannya adalah Ho ditolak dan Ha diterima sehingga dapat disimpulkan bahwa kualitas produk, desain, fitur dan promosi secara bersama sama berpengaruh signifikan terhadap minat beli konsumen Shopee.

\section{c) Uji Determinasi}

Koefisien determinasi ini digunakan untuk mengetahui seberapa besar pengaruh variabelvariabel bebas memiliki pengaruh terhadap variabel terikatnya. Nilai koefisien determinasi ditentukan dengan nilai adjusted $R$ square.

Tabel 6. Koefisien Determinasi

Model Summary

\begin{tabular}{|l|r|r|r|r|}
\hline Model & $\mathrm{R}$ & \multicolumn{1}{|c|}{ R Square } & \multicolumn{1}{|c|}{$\begin{array}{c}\text { Adjusted R } \\
\text { Square }\end{array}$} & $\begin{array}{c}\text { Std. Error of the } \\
\text { Estimate }\end{array}$ \\
\hline 1 & $.827^{\mathrm{a}}$ & .683 & .670 & 1.713 \\
\hline
\end{tabular}

a. Predictors: (Constant), promosi, fitur, kualitas, desain

b. Dependent Variable: minat konsumen

Sumber : Hasil pengolahan data primer, 2019

Besar kontribusi lokasi dan costumer relatinship management terhadap minat konsumen sebesar 0,683. Hal ini berarti 68,3\% Minat konsumen dipengaruhi oleh kualitas produk, desain, fitur dan promosi, sedangkan sisanya yaitu 31,7\% Minat konsumen dipengaruhi oleh variabel-variabel lainnya yang tidak diteliti dalam penelitian ini.

\section{Kesimpulan}

Sebagai penutup dari skripsi ini penulis akan mencoba untuk memberikan beberapa kesimpulan dan saran-saran yang diperlukan berdasarkan uraian dan asal analisa pada bab-bab sebelumnya. Adapun kesimpulan yang dapat diambil adalah:

1. Secara parsial variabel kualitas produk tidak berpengaruh signifikan terhadap minat konsumen berbelanja di Shopee dengan signifikansi 0,859

2. Secara parsial variabel desain berpengaruh signifikan terhadap minat konsumen berbelanja di Shopee dengan signifikansi 0,000

3. Secara parsial variabel fitur berpengaruh signifikan terhadap minat konsumen berbelanja di Shopee dengan signifikansi 0,016

4. Secara parsial variabel promosi berpengaruh signifikan terhadap minat konsumen berbelanja di Shopee dengan signifikansi 0,000

5. Secara simultan kualitas produk, desain, fitur dan promosi berpengaruh signifikan terhadap minat konsumen berbelanja di Shopee dengan signifikansi 0,000

\section{Referensi}

Alma, B. (2013). Marketing Management and Service Marketing. Bandung: Alfabeta.

Arif, M, Sabri, S, Nagara, P, Nasfi, N. (2020). SWOT Analisis dan Matrik SWOT Analisis Dalam Rangka Pemasaran Produk Pendanaan Bank (Studi PT. BPR Rangkiang Aur). Jurnal Point Equilibrium Manajenem \& Akuntansi, 2(1), 12-25.

Arikunto, S. (2012). Dkk. Penelitian Tindakan Kelas.

Basjaruddin, N. C., Rakhman, E., \& Renardi, M. B. (2017). Developing Electronic Medical

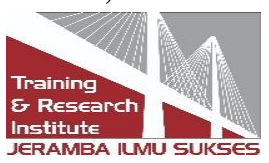


Record Based on NFC. Proceedings of the 2017 International Conference on Computer Science and Artificial Intelligence, 148-152.

Febriani, E. M. A. (2020). Pengaruh Kualitas Pelayanan E-Commerce Shopee terhadap Kepuasan Konsumen Shopee pada Mahasiswa Uin Suska Riau dengan Menggunakan Metode E-servqual. UNIVERSITS ISLAM NEGERI SULTAN SYARIF KASIM RIAU.

Firmansyah, M. A., \& SE, M. M. (2019). Perilaku Konsumen (Sikap dan Pemasaran). Penerbit Qiara Media.

Ghozali, I., \& Latan, H. (2015). Partial Least Squares: Konsep. Teknik Dan Aplikasi Menggunakan Program SmartPLS, 3.

Gunawan, G. G. (2009). Pengaruh Atribut Produk Terhadap Minat Beli Konsumen Pada Honda CR-V Di IBRM Bandung. Universitas Kristen Maranatha.

Hasim, D., Kusumo, N., \& Sugiyanto, S. (2020). Pengaruh Pelayanan Dan Promosi Terhadap Minat Konsumen Pada S Plus Indonesia. Proceedings Universitas Pamulang, 1(1).

Hismuddin, M. H., Arifin, R., \& Slamet, A. R. (2020). Pengaruh Kualitas Produk, Harga, Store Atmosphere, Promosi Dan Kualitas Pelayanan Terhadap Keputusan Pembelian Di Swalayan Mahkota Gresik (Studi Kasus Pada Konsumen Swalayan Mahkota). Jurnal Ilmiah Riset Manajemen, 9(10).

Indrianto, N., \& Supomo, B. (2011). Metode Penelitian Bisnis (keempat). Yogyakarta: BPFEYogyakarta.

Kara, A. (2016). Pengaruh Promosi Penjualan Pakaian Online Shop Elevenia Di BBM Grup Terhadap Minat Beli Mahasiswi. JISIP: Jurnal Ilmu Sosial Dan Ilmu Politik, 5(1).

Karnadjaja, C. C., Tulipa, D., \& Lukito, R. S. H. (2018). Pengaruh persepsi risiko, manfaat, dan kemudahan penggunaan terhadap minat belanja online melalui kepercayaan dan sikap pada konsumen Zalora di Surabaya. Kajian Ilmiah Mahasiswa Manajemen, 6(2), 116-130.

Kotler, P., \& Armstrong, G. (2015). Marketing an Introducing Prentice Hall. England: Pearson Education Inc.

Kusumawardhana, R. T. (2016). Pengaruh Atribut Produk Terhadap Minat Beli Konsumen Yamaha Vixion (Studi Kasus Pada Mahasiswa Widyatama Bandung). Universitas Widyatama.

Laheba, Y. A., Tumbuan, W. J. F. A., \& Soepeno, D. (2015). Pengaruh Citra Merek, Fitur dan Harga terhadap Keputusan Pembelian Handphone Samsung (Studi Pada Mahasiswa FEB Unsrat Manado). Jurnal EMBA: Jurnal Riset Ekonomi, Manajemen, Bisnis Dan Akuntansi, 3(3).

Meme, R., \& Byre, R. O. (2020). Pengaruh Promosi Terhadap Keputusan Pembelian Yang Di Mediasi Oleh Minat Beli Konsumen Roxy Swalayan Ende. Analisis, 20(II), 1-13.

Mustikasari, W. (2014). Pengaruh Kualitas Produk, Desain Produk dan Harga Terhadap Keputusan Pembelian Kopiah Merek Gading Gajah Gresik. Jurnal Pendidikan Tata Niaga (JPTN), 2(2).

Najmi, M. (2018). Akad Jual Beli Pada Shopee Menurut Fatwa DSN MUI NO. 110/DSNMUI/IX/2017 Tentang Akad Jual Beli. IAIN SURAKARTA.

Nasfi, Rahmad, S. (2020). Pengaruh Diklat Kepemimpinan Dan Pengembangan Karir Terhadap Kinerja Pegawai Dinas Koperasi UMKM Provinsi Sumatera Barat. Al-Fikrah: Jurnal Manajemen Pendidikan, 8(1), 11-28. https://doi.org/http://dx.doi.org/10.31958/jaf.v8i1.2025 
Nasfi, N., Rahmad, R., \& Sabri, S. (2020). Pengaruh Kualitas Pelayanan Terhadap Kepuasan Nasabah Perbankan Syariah. Ekonomika Syariah: Journal of Economic Studies, 4(1), 19-38. https://doi.org/10.30983/es.v4i1.3146

Nurmiati, N., Ibrahim, M. B. H., Irawan, A., \& Husen, S. (2020). Pengaruh Kualitas Produk, Desain Produk Dan Promosi Terhadap Keputusan Pembelian Motor Matic Honda Vario Di Kota Jayapura. The Journal of Business and Management Research, 3(1), 319-335.

Prabowo, A., \& Arofah, K. (2017). Media Sosial Instagram Sebagai Sarana Sosialisasi Kebijakan Penyiaran Digital. Jurnal Aspikom, 3(2), 256-269.

Rahmad, Sabri, \& Nasfi, N. (2020). Pengaruh Faktor Pribadi, Organiasi dan Non Organisasi Terhadap Komitmen Organisasi Karyawan Pada PT. PLN Area Bukittinggi. Jurnal Apresiasi Ekonomi, 8(1), 142-152. https://doi.org/https://doi.org/10.31846/jae.v8i1

Ramadonna, Y., Nasfi, N., \& Aziz, Z. (2019). The Effect Of Customer Relationship Management And Customer Value On Customer Satifsfaction Of Service And Its Impact on Customer Loyality In PT. BPR Rangkiang Aur. Jurnal Menara Ekonomi: Penelitian Dan Kajian Ilmiah Bidang Ekonomi, 5(1). https://doi.org/https://doi.org/10.31869/me.v5i1.1277

Rosniyenti, Sabri, N. (2020). Analisis Pengaruh Merek, Harga, dan Produk Terhadap Kepuasan Pelanggan Levi's Tailor Simpang Senggol Biaro Kab. Agam. Jurnal Ekonomi, 23(2), 97-116.

Rusmawan, U. (2018). Analisis Faktor-Faktor Yang Mempengaruhi Minat Beli Produk Digital Secara Online. Bina Insani ICT Journal, 1(1), 41-72.

Santoso, S. (2012). Aplikasi SPSS pada statistik parametrik. Jakarta: PT Elex Media Komputindo.

Sopiyan, Pipih Gunawan, K. (2018). Pengaruh Atribut Produk dan Kualitas Pelayanan Terhadap Keputusan Pembelia Pada Rumah Makan Panineungan Maja Kabupaten Majalengka. MAKSI, 5(2).

Sugiyono. (2014). Metode Penelitian Kuantitatif Kualitatif dan $R \& D$. Alfabeta.

Triandewi, E., \& Tjiptono, F. (2013). Consumer intention to buy original brands versus counterfeits. International Journal of Marketing Studies, 5(2), 23.

Wasis Ayu W, L. (2016). Pengaruh Kualitas Produk Dan Promosi Terhadap Keputusan Pembelian Produk Smartfren Andromax 4G/LTE Pada Mahasiswa Fakultas Ekonomi Universitas Negeri Surabaya. Jurnal Pendidikan Tata Niaga (JPTN), 3(3).

\section{Copyrights}

Copyright for this article is retained by the author(s), with first publication rights granted to the journal.

This is an open-access article distributed under the terms and conditions of the Creative Commons Attribution license (http://creativecommons.org/licenses/by/4.0/) 